\title{
Biochemical Characterization of Phenylacetaldehyde Dehydrogenases from Styrene-degrading Soil Bacteria
}

\author{
Juliane Zimmerling ${ }^{1}$ - Michel Oelschlägel ${ }^{1} \cdot$ Carolin Großmann $^{1} \cdot$ Matthias Voitel $^{1}$. \\ Michael Schlömann ${ }^{1} \cdot$ Dirk Tischler $^{1,2}$
}

Received: 4 April 2020 / Accepted: 11 September 2020 /

Published online: 27 October 2020

(C) The Author(s) 2020

\begin{abstract}
Four phenylacetaldehyde dehydrogenases (designated as FeaB or StyD) originating from styrene-degrading soil bacteria were biochemically investigated. In this study, we focused on the Michaelis-Menten kinetics towards the presumed native substrate phenylacetaldehyde and the obviously preferred co-substrate $\mathrm{NAD}^{+}$. Furthermore, the substrate specificity on four substituted phenylacetaldehydes and the co-substrate preference were studied. Moreover, these enzymes were characterized with respect to their temperature as well as long-term stability. Since aldehyde dehydrogenases are known to show often dehydrogenase as well as esterase activity, we tested this capacity, too. Almost all results showed clearly different characteristics between the FeaB and StyD enzymes. Furthermore, FeaB from Sphingopyxis fribergensis Kp5.2 turned out to be the most active enzyme with an apparent specific activity of $17.8 \pm 2.1 \mathrm{U} \mathrm{mg}^{-1}$. Compared with that, both StyDs showed only activities less than $0.2 \mathrm{U} \mathrm{mg}^{-1}$ except the overwhelming esterase activity of StyD-CWB2 $\left(1.4 \pm 0.1 \mathrm{U} \mathrm{mg}^{-1}\right)$. The clustering of both FeaB and StyD enzymes with respect to their characteristics could also be mirrored in the phylogenetic analysis of twelve dehydrogenases originating from different soil bacteria.
\end{abstract}

Keywords Oxidoreductase $\cdot \mathrm{NAD}^{+} \cdot$ Maximum reaction rate $\cdot$ Michaelis constant $\cdot$ Turnover number $\cdot$ Evolutionary ancestry $\cdot$ Esterase activity

Electronic supplementary material The online version of this article (https://doi.org/10.1007/s12010-02003421-8) contains supplementary material, which is available to authorized users.

Juliane Zimmerling

Juliane.Zimmerling@ioez.tu-freiberg.de

Dirk Tischler

dirk.tischler@rub.de

1 Interdisciplinary Ecological Center, Environmental Microbiology Group, TU Bergakademie Freiberg, Leipziger Str. 29, 09599 Freiberg, Germany

2 Microbial Biotechnology, Faculty of Biology and Biotechnology, Ruhr-Universität Bochum, Universitätsstr. 150, 44780 Bochum, Germany 


\section{INTRODUCTION}

Aldehyde dehydrogenases (ALDHs, EC 1.2.1) comprise a huge group of enzymes occurring in every organism ranging from bacteria and fungi to invertebrates and mammals [1]. Enzymes belonging to this class transform a wide range of substrates during different metabolic routes, and they are strictly co-substrate-dependent. The substrate spectra of these enzymes comprise aldehydes which are oxidized to acids while reducing $\mathrm{NAD}(\mathrm{P})^{+}$.

By means of the 145 aligned ALDHs, ten conserved motifs could be detected [1]. Four of them were allocated to the co-substrate binding region and three to the catalytic site. On the basis of the three catalytic amino acids cysteine, glutamate and asparagine, the catalytic mechanism of ALDHs can be explained as follows. The three amino acids mentioned above form in general a catalytic triad supporting the redox catalysis. The thiol group of cysteine is activated via deprotonation by the glutamate residue and then binds temporarily to the carbonyl $\mathrm{C}$ of the substrate. Thereby, it supports the elimination of a hydride from the carbonyl C. The hydride mentioned is directly transferred to $\mathrm{NAD}(\mathrm{P})^{+}$and $\mathrm{NAD}(\mathrm{P}) \mathrm{H}+\mathrm{H}^{+}$is released while the proton originates from glutamate. Subsequently, glutamate deprotonates a water molecule in the next step and a hydroxide ion is formed. This ion can attack the carbonyl $\mathrm{C}$ as a nucleophile leading to an organic acid as product. During this transformation, asparagine stabilizes the carbonyl $\mathrm{O}$ and the meanwhile occurring oxyanion [2, 3]. The catalytic triad mentioned above is also responsible for the often observed esterase activity of these ALDHs.

In this above-mentioned study of 1999, 145 ALDH sequences were aligned. On the basis of this alignment, a phylogenetic tree was constructed which is subdivided into two main trunks [1]. One main trunk consists of class 3 ALDHs (eight families), the other one of class 1 (one family), and 2 ALDHs (five families). Class 1 and 2 ALDHs have various substrate spectra except for two enzyme families. In contrast, nearly all class 3 ALDH representatives are very substrate-specific and occur as homotetramer [2, 4]. Perozich and coworkers [4] proposed that the substrate-unspecific enzymes diverged later in evolution than the substrate-specific ALDHs. The substrate specificity likely depends on the aim which is pursued in the metabolic context. Basic cellular metabolic pathways require substrate-specific biocatalysts, whereas enzymes with unspecific substrate spectra are most suitable to metabolize xenobiotics. Maybe, this is a strategy to occupy ecological niches. Furthermore, nearly each family has a clear cosubstrate preference, and the majority of these enzymes belonging to the same families occurred from bacteria to humans. Nevertheless, three families were only found in certain kingdoms like the aromatic, fungal and class 1 ALDHs. The last-mentioned ones were only detected in animals, and the aromatic ALDHs were found exclusively in bacteria [1].

In our study, we focused on bacterial ALDHs, especially phenylacetaldehyde dehydrogenases (PADs) originating from the upper pathway of the microbial styrene metabolism. The aerobic styrene degradation can be divided into two routes, the side-chain oxygenation and the direct ring cleavage [5]. The side-chain oxygenation consists of the upper and the lower pathway. Three enzymes operate sequentially in the upper styrene catabolic pathway. First, the styrene monooxygenase (SMO) forms the reactive styrene oxide which is then isomerized to phenylacetaldehyde by the styrene oxide isomerase (SOI). Now, the aldehyde is oxidized by a PAD to phenylacetic acid [6]. Phenylacetic acid product of the upper styrene catabolic pathway is transformed into acetyl-CoA and succinyl-CoA through the following enzymatic transformations in the lower styrene catabolic pathway [7].

So far, especially SMOs and SOIs of different microorganisms were studied in detail [8]. The PADs studied, so far, originate from the bacteria Pseudomonas fluorescens ST [9], 
Pseudomonas putida S12 [2], Escherichia coli K-12 [10-13], Escherichia coli ATCC 11105 W [10], Arthrobacter globiformis [14], Xanthobacter sp. 124X [15], Rhodococcus rhodochrous [6], and the fungus Exophiala jeanselmei [16]. In contrast to SMOs and SOIs, the PADs have been less extensively characterized in terms of their suitability for biotechnological applications.

The products of the PAD — phenylacetic acids and derivatives thereof - are industrially very important because they are often employed in different fields. They are applied as flavors and fragrances in honey and wax $[17,18]$. Moreover, they are used as precursors of cosmetic [19] and pharmaceutical products. 4-Methyl phenylacetic acids are applied for production of drugs against cancer [20,21], 4-fluoro phenylacetic acids for medicine used during disorder of gastrointestinal tract, bladder, and nervous system [22]. There are numerous other areas of applications for phenylacetic acids but the probably best known are both analgetics Ibuprofen (4-isobutyl- $\alpha$-methylphenylacidic acid; CAS 15687-27-1) [23] and Diclofenac (2-(2,6dichloroanilino)phenylacetic acid; CAS 15307-86-5) [24]. Nowadays, phenylacetic acids are produced by numerous chemical syntheses which are often harmful to the environment [17, $25,26]$. Therefore, the biotechnological production of can be an eco-friendly alternative. The precondition for novel phenylacetic acid synthesis routes are detailed studies about the required enzymes like PADs.

In this work, we especially studied PADs of the styrene-degrading soil bacteria Rhodococcus opacus 1CP, Gordonia rubripertincta CWB2, and Sphingopyxis fribergensis Kp5.2. Moreover, we executed further experiments towards the recently characterized FeaB of E. coli K-12 [13]. Understanding the function and applicability of those enzymes will allow to add it towards enzymatic cascades producing valuable phenylacetic acid derivatives. In order to choose a proper candidate PAD, we need to know more about their activity and stability which were investigated herein.

\section{Materials and Methods}

\section{Chemicals, Kits, and Plasmids}

All chemicals used were purchased from AppliChem, Carl Roth, Fluka, Merck, Riedel-deHaën, Sigma-Aldrich, and VWR International. Both kits, GeneJET Plasmid Miniprep and CloneJET PCR Cloning, were acquired from Thermo Fisher Scientific, whereas the innuPREP Gel Extraction Kit from Analytik Jena was applied. The expression vector pET16bP was handled as described earlier [27].

\section{Bacteria, Cultivation, Expression Conditions, and Cell Harvesting}

The styrene-degrading bacterium Sphingopyxis fribergensis Kp5.2 (DSM 28731, accession number SAMN02872841) [28] was cultivated with mineral media (Brunner, DSMZ medium 462 ) at $\mathrm{pH} 6.9$ with $100 \mathrm{mM}$ glucose at $30^{\circ} \mathrm{C}$. The cloning strain Escherichia coli NEB5 $\alpha$ (New England Biolabs) and the expression strain Escherichia coli BL21 (DE3) pLysS were cultivated with LB media at $\mathrm{pH} 7.1$ and with $100 \mu \mathrm{g} \mathrm{mL}-1$ ampicillin $(E$. coli NEB5 $\alpha$ ) or with $100 \mu \mathrm{g} \mathrm{mL}{ }^{-1}$ ampicillin together with additionally added $35 \mu \mathrm{g} \mathrm{mL}^{-1}$ chloramphenicol (E. coli BL21 (DE3) pLysS) for $14-18 \mathrm{~h}$ at $37^{\circ} \mathrm{C}$. In case of a pre-cultivation on solid medium, $15 \mathrm{~g} \mathrm{~L}^{-1}$ agar were additionally added. Liquid cultures were incubated under constant shaking at 
$120 \mathrm{rpm}$ in baffled flasks or tubes. The cultivation and cell harvesting of Escherichia coli BL21 (DE3) pLysS (pET16bP+feaB-K-12) as well as the FeaB-K-12 preparation were performed as described earlier [13].

To obtain a maximum yield of recombinant protein, expression studies with different media (pre-cultures: LB at $\mathrm{pH} 7.1$, inoculation: $1 \%(\mathrm{v} / \mathrm{v})$ of pre-culture, main cultures containing 10 $\mathrm{mL}$ of LB, LBNB, DYT, TB at $\mathrm{pH} 7.1)$, expression durations ( $6 \mathrm{~h}, 12 \mathrm{~h}, 18 \mathrm{~h}, 24 \mathrm{~h})$, and temperatures $\left(22{ }^{\circ} \mathrm{C}, 30{ }^{\circ} \mathrm{C}, 37^{\circ} \mathrm{C}\right)$ were performed for FeaB-Kp5.2 and both StyDs.

The subsequent main cultures for the final expressions contained $800 \mathrm{ml}$ DYT medium at pH 7.1 (FeaB-Kp5.2) and $1000 \mathrm{ml} \mathrm{TB}$ medium at pH 7.1 (both StyDs) with the abovementioned antibiotics. For FeaB-Kp5.2 expression, 1\% (v/v) of the pre-cultures in TB medium at $\mathrm{pH} 7.1$ was directly used for inoculation. For StyD expression, $1 \%(\mathrm{v} / \mathrm{v})$ of the precultures containing LB medium at $\mathrm{pH} 7.1$ was centrifuged $\left(5000 x \mathrm{~g}, 4{ }^{\circ} \mathrm{C}, 5 \mathrm{~min}\right)$ and washed once with $25 \mathrm{mM}$ phosphate buffer $(\mathrm{pH} 7.3)$ to remove the medium ingredients. The pellets obtained after subsequent centrifugation $\left(5000 x \mathrm{~g}, 4{ }^{\circ} \mathrm{C}, 5 \mathrm{~min}\right)$ were resuspended in $10 \mathrm{ml}$ fresh $\mathrm{TB}$ medium at $\mathrm{pH} 7.1$, and cell suspensions were added to the main cultures. Until an $\mathrm{OD}_{600}$ of about $0.4-0.5$ was reached, all cultures were incubated at $37^{\circ} \mathrm{C}$. Afterwards, $0.1 \mathrm{mM}$ isopropyl- $\beta$-D-thiogalactopyranoside was added, and the incubation was continued at the optimized conditions for every protein as mentioned in the "Results" section.

The harvesting of the cultures was performed at $5000 \times \mathrm{g}$ and $4{ }^{\circ} \mathrm{C}$ for $20 \mathrm{~min}$. Afterwards, the pellets were washed once in $25 \mathrm{mM}$ phosphate buffer ( $\mathrm{pH} 7.3)$ and centrifuged (5000 x g, 4 ${ }^{\circ} \mathrm{C}, 30 \mathrm{~min}$ ) again. The cells were resuspended in the same buffer and stored at $-20{ }^{\circ} \mathrm{C}$ until cell disruption.

\section{Cloning of $f e a B$ and Gene Synthesis of $s t y D$ Genes}

The wildtype gene $f e a B-K p 5.2$ (AJA07149.1; sequence attached in supplemental material) originating from strain $S$. fribergensis Kp5.2 was amplified by PCR with the specific primers FeaB-Kp52-fw 5'-CATATGGCAACGGCGCAATCCTAC-3' and FeaB-Kp52-rev 5'GCGGCCGCTTAGTGCGCGATGCACACG-3'. The reaction mixture with a final volume of $50 \mu \mathrm{L}$ consists of $5-\mu \mathrm{L} 10 \mathrm{x}$ Dream Taq buffer; $0.5 \mu \mathrm{M}$ of each primer; $0.08 \mathrm{mM}$ of dATP, dTTP, dCTP, dGTP; and 25 ng extracted genomic DNA of S. fribergensis Kp5.2 as well as 2.5 $\mathrm{U}$ of DreamTaq polymerase. The PCR was performed corresponding to DreamTaq polymerase instruction (Thermo Fisher Scientific), and an annealing temperature of $52.0{ }^{\circ} \mathrm{C}$ was adjusted. The subsequent steps of cloning and transforming were carried out as described in an earlier study [13]. For revision of the cloning success, the cloning product was restricted by NotI as well as NdeI, and the restriction product was subjected to a gel electrophoresis.

The wildtype genes styD-1CP-W (KT923291) originating from $R$. opacus 1CP (VKM Ac2638) [29] and styD-CWB2-W (KT923294) originating from G. rubripertincta CWB2 (DSM 46758) [30] were optimized using the online tool OPTIMIZER [31]. The codon usage of Acinetobacter sp. ADP1 was selected. Restriction sites, which were selected for subsequent cloning, were prevented inside the gene sequence and attached on the flanks of the gene. The optimized gene sequences for styD-1CP (KT923292, Gene sequence 2 in Supplemental Material section) and styD-CWB2 (KT923295, Gene sequence 3 in Supplemental Material section) were synthesized and ligated into the vector pET16bP by MWG Eurofins. The expression system pET16bP provides a 10-Histidine tag at the $N$-terminal site [27].

The vectors containing the genes of interest were transformed into E. coli BL21 (DE3) pLysS and cultivated as mentioned above. 


\section{Preparation of PAD}

For further studies towards FeaB-K-12, the already existing expression strain E. coli BL21 (DE3) pLysS (pET16bP+feaB-K-12) was used and cultivated as described earlier [13].

For the preparation of the three recombinantly produced PADs FeaB-Kp5.2, StyD$1 \mathrm{CP}$, and StyD-CWB2, the appropriate E. coli BL21 (DE3) pLysS strains were cultivated and harvested as mentioned above. $40 \mathrm{U}$ DNase I were added to the thawed cell suspensions. Then, the disruption was performed by three passages through a cooled French press at $1500 \mathrm{psi}$. The crude extract was centrifuged at 50,000 $\mathrm{xg}$ and $4{ }^{\circ} \mathrm{C}$ for $1 \mathrm{~h}$ to separate the insoluble cell components from the soluble protein fraction. Afterwards, the soluble proteins obtained were subjected to protein purification by means of Ni-affinity chromatography via fast protein liquid chromatography (FPLC) as described elsewhere [27]. First, the supernatant was loaded, and unspecific proteins were removed with washing buffer $(300 \mathrm{mM} \mathrm{NaCl}, 20 \mathrm{mM}$ Tris-HCl, $\mathrm{pH}$ 7.5). To elute the proteins bounded, an elution buffer ( $300 \mathrm{mM} \mathrm{NaCl}, 20 \mathrm{mM}$ Tris- $\mathrm{HCl}, \mathrm{pH}$ 7.5, 500-mM imidazole) was used and a linear gradient of imidazole from $25-500 \mathrm{mM}$ was adjusted. The fractions were screened for dehydrogenase activity using the below-mentioned assay, and active fractions were pooled. In case of FeaB-Kp5.2, the protein preparation was subjected to dialysis over night as described earlier [32], and finally, an equal volume of $99 \%$ glycerol (v/v) was added for storage at $-20{ }^{\circ} \mathrm{C}$. Both StyDs were transferred from elution to storage buffer via ultrafiltration using Vivaspin centrifugal concentrators (Vivaproducts, Inc.). Therefore, the sample was centrifuged at $4{ }^{\circ} \mathrm{C}$ and $5000 \times \mathrm{g}$ until a residual volume of $1 \mathrm{~mL}$. Afterwards, phosphate buffer $(\mathrm{pH}$ 7.7) was added and centrifuged again. The protein solution received was diluted with phosphate buffer $(\mathrm{pH}$ 7.7) to the initial volume. An equal volume glycerol was added, mixed carefully and stored at $-20{ }^{\circ} \mathrm{C}$. The success of all expression studies and purification procedures was monitored via sodium dodecyl sulfate polyacrylamide gel electrophoresis (SDS-PAGE) as mentioned previously [13]. The concentration of enzyme preparation was monitored by Bradford method employing a bovine serum albumin standard as reference [33].

\section{Biochemical Characterization}

The dehydrogenases activity was measured using the two-step enzyme assay at $\mathrm{pH} 7.7$ which was described earlier by Zimmerling and coworkers [13]. The activity measurements were performed spectrometrically (SpectraMax M2e, Molecular Devices) because the formation of phenylacetic acids can be monitored indirectly by $\mathrm{NAD}(\mathrm{P}) \mathrm{H}$ increase at $340 \mathrm{~nm}$. In addition, product formation was verified by RP-HPLC (Dionex Ultimate 3000: pump, autosampler, diode array detector; software: Chromeleon 7; stationary phase: Knauer C18 Eurospher sorbens: pore size $100 \AA$, particle size $5 \mu \mathrm{m}$, column length $125 \mathrm{~mm}$ and inner diameter $4 \mathrm{~mm}$; mobile phase: 50\% methanol, 50\% water with $2 \mathrm{~g} \mathrm{~L}^{-1} \mathrm{H}_{3} \mathrm{PO}_{4}$, flow rate $0.7 \mathrm{~mL} \mathrm{~min}^{-1}$; injection volume $10 \mu \mathrm{L}$; absorbance range 200 $300 \mathrm{~nm}$ ), and on the basis of available standards, the retention volumes and specific spectra were verified. Applying this assay, styrene oxides are completely transformed into corresponding phenylacetaldehydes (PA) during the first step by enriched SOI-1CP [13]. In the second step, the aldehydes obtained can be used as putative substrates for dehydrogenases. Thus for simplification, it is spoken of (substituted) phenylacetaldehyde 
as substrate in this publication although the corresponding styrene oxides - completely transformed by the SOI-1CP into the PA before the start for the dehydrogenase activity measurements - were used expect $\alpha$-methyl phenylacetaldehyde. The following enzyme amounts were applied: 2.8-3.4 ng FeaB-K-12, 1.6-29 ng FeaB-Kp5.2, 37-119 ng StyD1CP, and 9.2-115 ng StyD-CWB2, respectively. First, the Michaelis-Menten kinetics for $\mathrm{NAD}^{+}$(FeaB-Kp5.2: 0- $10 \mathrm{mM}$; StyDs: 0-8 mM; PA standard concentration: $0.5 \mathrm{mM}$ ) were investigated. The consequential suitable $\mathrm{NAD}^{+}$concentrations (Table 1) were applied to study Michaelis-Menten kinetics for PA (FeaB-Kp5.2: 0.1-1.0 mM; StyD1CP: 0-1.5 mM; StyD-CWB2: 0.005-0.1 mM). Moreover, the identification of the most suitable cofactor was studied applying $0.5 \mathrm{mM}$ phenylacetaldehyde and the following cofactor concentrations for the three enzymes: $2.5 \mathrm{mM} \mathrm{NAD}^{+}$and $\mathrm{NADP}^{+}$as well as $2.5 \mathrm{mM}$ phenazine methosulfate (PMS) (FeaB-Kp5.2), 6.0 (StyD-1CP) and $2.0 \mathrm{mM}$ $\mathrm{NAD}^{+}$(StyD-CWB2), $5.0 \mathrm{mM} \mathrm{NADP}{ }^{+}$(both StyDs). Furthermore, the ability of all four dehydrogenases to convert different substituted phenylacetaldehydes (4-chloro-, 4fluoro-, $\alpha$-methyl-) was studied by applying $0.5 \mathrm{mM}$ substrate and the most suitable $\mathrm{NAD}^{+}$concentration for each dehydrogenase (Table 1).

Other important characteristics, especially with regard to biotechnological applications, are the behavior of the enzyme after storage at $-20{ }^{\circ} \mathrm{C}$ for about 3 months as well as the enzyme's temperature stability over a range of -20 up to $55{ }^{\circ} \mathrm{C}$. The behavior of FeaB-Kp5.2 towards these special conditions was studied by applying the most applicable $\mathrm{NAD}^{+}(2.5 \mathrm{mM})$ and standard PA $(0.5 \mathrm{mM})$ concentration. StyD$\mathrm{CWB} 2$ was also tested for protein stability at $-20{ }^{\circ} \mathrm{C}$ overtime using $2.0 \mathrm{mM} \mathrm{NAD}^{+}$ and $0.5 \mathrm{mM}$ PA.

Besides the activity to oxidize (phenylacet)aldehydes to the corresponding acids, formerly studied dehydrogenases showed an esterase activity, too [10, 32, 34, 35]. This conversion can be screened by a photometric method. Thereby, enzymes catalyze the hydrolysis of $p$-nitrophenyl acetate to acetic acid and $p$-nitrophenol. The increase of the last-mentioned product can be easily measured at $400 \mathrm{~nm}$. The esterase activity of the four dehydrogenases was tested by using the assay described previously [10] under application of the optimal $\mathrm{NAD}^{+}$concentration of each enzyme. We applied $20 \mu \mathrm{L}$ of $2.5 \mathrm{mM} p$-nitrophenyl acetate in $1000-\mu \mathrm{L}$ assay at $\mathrm{pH}$ 7.7. Furthermore, we determined the molar extinction coefficient under these conditions.

Table 1 Values of Michaelis-Menten kinetics and the turnover number $\mathrm{k}_{\text {cat }}$ (app) for FeaBs and StyDs towards $\mathrm{NAD}^{+}$and phenylacetaldehyde

\begin{tabular}{|c|c|c|c|c|c|c|}
\hline Enzyme & $\begin{array}{l}\text { Substrate } \\
\text { (varied) } \\
{\left[\mathrm{mmol} \mathrm{L}^{-1}\right]}\end{array}$ & $\begin{array}{l}\text { Substrate } \\
\text { (fixed) } \\
{\left[\mathrm{mmol} \mathrm{L}^{-1}\right]}\end{array}$ & $\begin{array}{l}\mathrm{V}_{\max }(\mathrm{app})^{\mathrm{a}} \\
{\left[\mathrm{U} \mathrm{mg}^{-1}\right]}\end{array}$ & $\begin{array}{l}\mathrm{K}_{\mathrm{M}}(\mathrm{app})^{\mathrm{a}} \\
{\left[\mathrm{mmol} \mathrm{L}^{-1}\right]}\end{array}$ & $\begin{array}{l}\mathrm{k}_{\mathrm{cat}}(\mathrm{app})\left[\mathrm{min}^{-}\right. \\
1]\end{array}$ & Reference \\
\hline \multirow[t]{2}{*}{ FeaB-Kp5.2 } & $\mathrm{NAD}^{+}: 0-10.0$ & PA: 0.5 & $17.8 \pm 2.1$ & $0.5 \pm 0.3$ & 3752 & \multirow[t]{2}{*}{ This study } \\
\hline & PA: $0-1.0$ & $\mathrm{NAD}^{+}: 2.5$ & $14.8 \pm 0.3$ & $0.022 \pm 0.005$ & 3119 & \\
\hline \multirow[t]{2}{*}{ StyD-1CP } & $\mathrm{NAD}^{+}: 0-8.0$ & PA: 0.5 & $0.039 \pm 0.001$ & $0.38 \pm 0.06$ & 9 & \multirow[t]{2}{*}{ This study } \\
\hline & PA: $0-1.5$ & $\mathrm{NAD}^{+}: 6.0$ & $0.095 \pm 0.002$ & $0.04 \pm 0.01$ & 20 & \\
\hline \multirow[t]{2}{*}{ StyD-CWB2 } & $\mathrm{NAD}^{+}: 0-8.0$ & PA: 0.5 & $0.047 \pm 0.002$ & $0.08 \pm 0.02$ & 10 & \multirow[t]{2}{*}{ This study } \\
\hline & PA: $0-0.1$ & $\mathrm{NAD}^{+}: 2.0$ & $0.12 \pm 0.02$ & $0.06 \pm 0.02$ & 25 & \\
\hline \multirow[t]{2}{*}{ FeaB-K-12 } & $\mathrm{NAD}^{+}: 0-8.0$ & PA: 0.5 & $6.5 \pm 0.2$ & $0.50 \pm 0.05$ & 1396 & \multirow[t]{2}{*}{ [13] } \\
\hline & PA: $0-1.25$ & $\mathrm{NAD}^{+}: 5.0$ & $6.7 \pm 0.1$ & $0.018 \pm 0.004$ & 1439 & \\
\hline
\end{tabular}

${ }^{a}$ Data shown are averages of independently measured triplicates 


\section{RESULTS}

\section{Identification of Phenylacetaldehyde Dehydrogenases among Soil Bacteria}

A phenylacetaldehyde dehydrogenase from Pseudomonas putida S12 [2] was used as start to genome mining approach for $s t y D$ or $f e a B$ genes in well-known styrene degrading bacteria [8, 11, 28, 36-38]. As candidate strains, we had chosen $R$. opacus 1CP, $S$. fribergensis Kp5.2, and G. rubripertincta CWB2 as those have been determined to provide different organizations in their styrene-degrading properties. This is reflected by different organizations of genes relevant for the upper styrene degradation pathways in respective soil bacteria (Fig. 1). The sty gene organization partially differs between the studied soil microorganisms. R. opacus 1CP [39] and P. putida S12 [2] harbor the "classic" sty operon with the order of the sty genes identically to the enzymatic cascade - the SMO is encoded by sty $A$ and $\operatorname{sty} B$, the SOI by sty $C$, and the PAD by sty $D$. However, in the genome of $G$. rubripertincta CWB2 styD is located far away and upstream from the sty $A$ and $s t y B$, and no sty $C$ could be found [36]. S. fribergensis Kp5.2 owns $s t y A, s t y B$, and $s t y C$ but not $s t y D$. Indeed, a gene belonging originally to the phenylethylamine degradation called $f e a B$ is located upstream the $\operatorname{sty} A B C$ operon $[11$, 38]. This gene product FeaB-Kp5.2 acts like the StyD proteins of the other bacteria.

In contrast to the other bacteria, $R$. opacus $1 \mathrm{CP}$ has additionally a SOI-like protein StyC2 [38], and P. putida S12 harbors two regulatory proteins StyS (AJA17111) and StyR styR (AJA17112) directly in front of styABCD.

The comparison of the PAD nucleotide sequences shown in Fig. 1 revealed the maximum identity of $77 \%$ between StyD-CWB2 and StyD-1CP, by far. All other protein sequences have identities in the range of $44-47 \%$ to each other.

Rhodococcus opacus 1CP

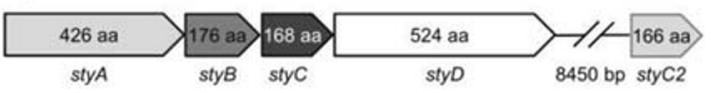

Pseudomonas putida $\mathrm{S} 12$

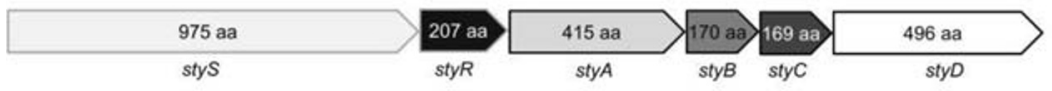

Gordonia rubripertincta CWB2

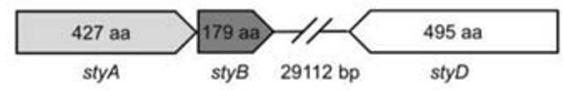

Sphingopyxis fribergensis Kp5.2

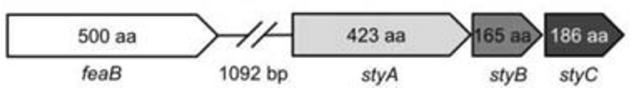

Fig. 1 Comparison of the sty genes organization of Rhodococcus opacus 1CP (CP009112) [39], Pseudomonas putida S12 (CP009975) [2], Gordonia rubripertincta CWB2 (CP022580) [36], and Sphingopyxis fribergensis Kp5.2 (CP009122) [38]. The genes involved in the upper styrene metabolism are sty $A$ and $s t y B$ (encode the $\mathrm{SMO}$ ), $s t y C$ (encodes the SOI), $s t y D$, and $f e a B$ (encode the PAD), respectively. The gene $s t y C 2$ encodes a protein similar to StyC, and the protein products of $s t y S$ and $s t y R$ are a sensor and a regulator proteins [38] 


\section{Cloning, Gene Synthesis, and Expression Studies}

For revision of the cloning success of $f e a B-K p 5.2$, the cloning product was restricted by specific restriction enzymes (NotI, NdeI), and a gel electrophoresis was performed. We gained fragment bands in the expected size of $1500 \mathrm{bp}$ (not shown). Therefore, the successful cloning of feaB-Kp5.2 (Gene sequence 1, Supplemental Material) by PCR using specific primers could be verified. The genes $s t y D-1 C P$ (Gene sequence 2, Supplemental Material) and sty $D$-CWB2 (Gene sequence 3, Supplemental Material) were optimized with respect to the codon usage, synthesized, and verified via standard single strand sequencing by MWG Eurofins (not shown). Finally, the genes of interest were ligated into the expression vector $\mathrm{pET} 16 \mathrm{bP}$ and cloned into the expression strain E. coli BL21 (DE3) pLysS as described previously for other genes $[13,27]$. The StyD and FeaB expression strains obtained were subjected to gene expression studies to gain maximum amounts of active proteins. The highest amount of enzyme was formed at $22{ }^{\circ} \mathrm{C}$ and in TB medium at $\mathrm{pH} 7.1$ after $24 \mathrm{~h}$ (StyD-1CP), $6 \mathrm{~h}$ (StyD-CWB2), or in DYT medium at pH 7.1 after 20 h (FeaB-Kp5.2), respectively. Therefore, these optimized conditions were used for all following gene expression experiments in order to produce proteins for subsequent studies.

\section{Protein Enrichment by FPLC and Verification by SDS-PAGE}

The recombinantly produced His ${ }_{10}$-tagged proteins FeaB-Kp5.2 and FeaB-K-12 as well as StyD-1CP and StyD-CWB2 were enriched by FPLC as mentioned above. The proteins eluted at the following imidazole concentration in the below-mentioned volume: FeaB-Kp5.2 in 16 $\mathrm{mL}$ at $175-410 \mathrm{mM}$, StyD-1CP in $8 \mathrm{~mL}$ at $260 \mathrm{mM}$, and StyD-CWB2 in 12-16 $\mathrm{mL}$ at $425-$ $500 \mathrm{mM}$ imidazole. The protein fractions obtained were investigated for phenylacetaldehyde dehydrogenase activity applying the two-step enzyme assay [13]. Active protein fractions were diluted with the same volume of glycerin (99\%) and stored as described previously [13].

The success of enrichment via FPLC and all expression studies was monitored by SDSPAGE. The enzyme-containing cell suspension, the supernatant after separation from disrupted cells as well as the FPLC fractions were controlled (Fig. S1). In the case of FeaBKp5.2 and StyD-CWB2, a complete purification could be proven while the enzyme from strain $1 \mathrm{CP}$ was considerably purified. The protein concentrations of the pooled and pure FPLC fractions were measured using the Bradford method as described in "Materials and Methods" section. The optimized conditions for PAD expression led to a high amount of active enzyme for the following characterization experiments. We obtained up to $4.8 \mathrm{mg}$ StyD-CWB2 in 2.0 L, 2.6 mg StyD-1CP in 1.8 L, and 27.9 mg FeaB-Kp5.2 in 1.6 L culture volume, respectively.

\section{Biochemical Characterization}

The recombinantly produced and purified dehydrogenases FeaB-Kp5.2, StyD-1CP, and StyDCWB2 were studied regarding their biochemical behavior applying the two-step enzyme assay [13]. Especially, the Michaelis-Menten kinetics for the co-substrate $\mathrm{NAD}^{+}$and the substrate phenylacetaldehyde were investigated (Fig. 2, Table 1). First, the kinetics of $\mathrm{NAD}^{+}$were studied using a constant phenylacetaldehyde (PA) concentration of $0.5 \mathrm{mmol} \mathrm{L}^{-1}$. Afterwards, the PA concentrations were varied, and the most suitable $\mathrm{NAD}^{+}$concentration depending on the enzyme (FeaB-Kp5.2: 2.5; StyD-1CP: 6.0; StyD-CWB2: $2.0 \mathrm{mmol} \mathrm{L}^{-1}$ ) was used (Fig. 2). FeaB-Kp5.2 showed maximum reaction rates $\left(\mathrm{V}_{\max }(\mathrm{app})\right)$ of $17.8 \pm 2.1 \mathrm{U} \mathrm{mg}^{-1}$ for $\mathrm{NAD}^{+}$and 

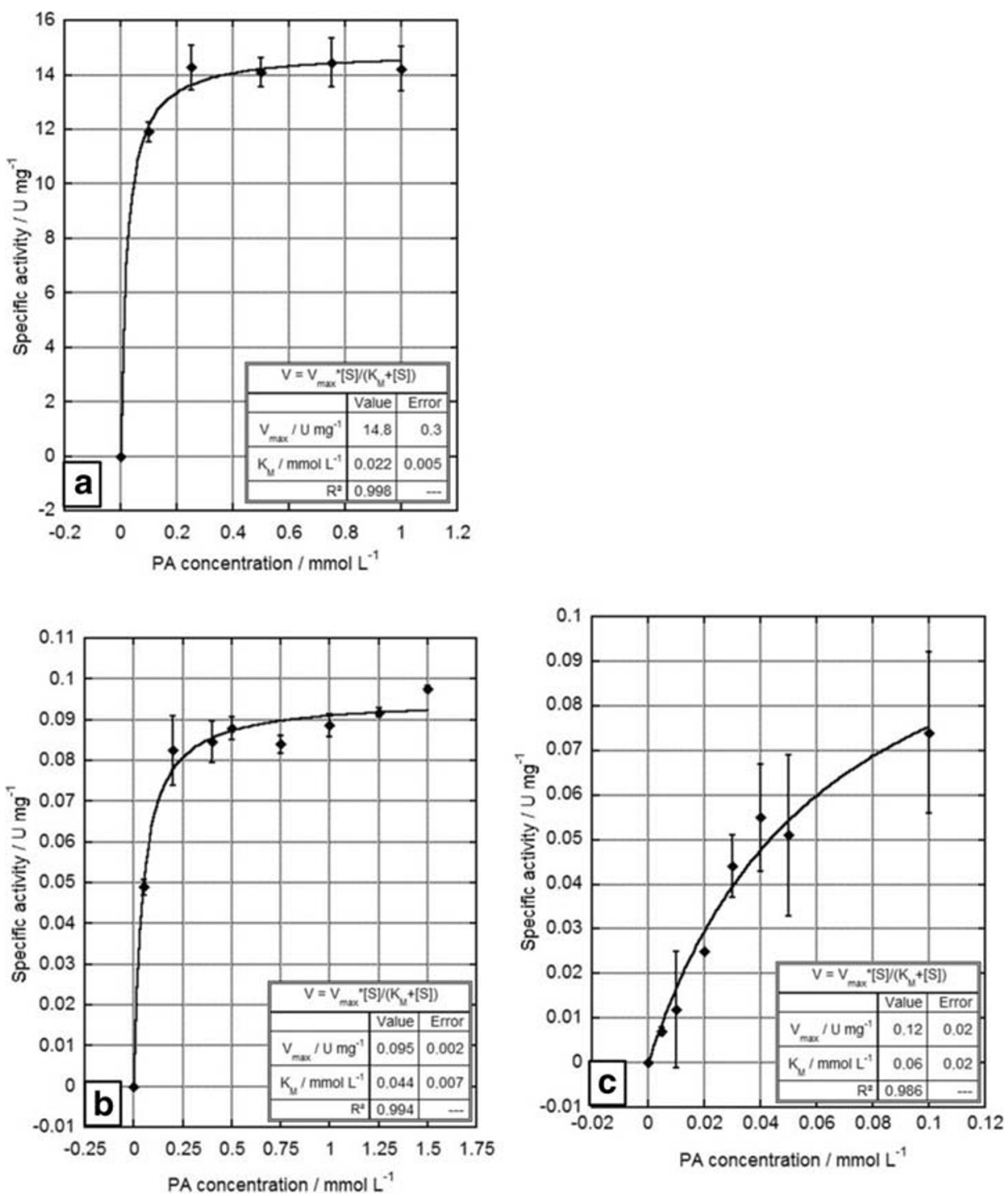

Fig. 2 Michaelis-Menten plots of (a) FeaB-Kp5.2, (b) StyD-1CP, and (c) StyD-CWB2 activities using different concentrations of phenylacetaldehyde. The assay was performed as mentioned in the "Materials and Methods" section. Various PA concentrations 0-1.0 (FeaB-Kp5.2), 0-1.5 (StyD-1CP), and 0-0.1 mmol L-1 (StyD-CWB2) were applied, while the most suitable NAD ${ }^{+}$concentration (FeaB-Kp5.2: 2.5; StyD-1CP: 6.0; StyD-CWB2: $2.0 \mathrm{mmol} \mathrm{L}^{-1}$ ) was set corresponding to each enzyme. Data shown are averages of independently measured triplicates

$14.8 \pm 0.3 \mathrm{U} \mathrm{mg}^{-1}$ for PA. For StyD-1CP and StyD-CWB2, the $\mathrm{V}_{\max }(\mathrm{app})$ values of $\mathrm{NAD}^{+}$ kinetic were $0.039 \pm 0.001 \mathrm{U} \mathrm{mg}^{-1}$ and $0.047 \pm 0.002 \mathrm{U} \mathrm{mg}^{-1}$. Remarkably, the activities for PA kinetic were about 2.5 times higher $\left(0.095 \pm 0.002 \mathrm{U} \mathrm{mg}^{-1}\right.$ for StyD-1CP and $0.12 \pm 0.02$ $\mathrm{U} \mathrm{mg}^{-1}$ for StyD-CWB2) than those for the co-substrate.

Furthermore, the behavior of three PADs was studied comparing the enzyme activities towards $\mathrm{NAD}^{+}$and NADP ${ }^{+}$. In the case of FeaB-Kp5.2, PMS was also investigated as potential co-substrate (Table 2). This study revealed the same tendency for all enzymes. The most suitable cofactor was 
$\mathrm{NAD}^{+}$. The following enzyme activities could be measured for a standard biotransformation using $\mathrm{NAD}^{+}: 13.9 \pm 0.7 \mathrm{U} \mathrm{mg}^{-1}$ (FeaB-Kp5.2), $0.068 \pm 0.001 \mathrm{U} \mathrm{mg}^{-1}$ (StyD-1CP), and $0.0356 \pm 0.0001 \mathrm{U}$ $\mathrm{mg}^{-1}$ (StyD-CWB2). For NADP ${ }^{+}$, the residual activities were $0.6 \pm 0.2 \mathrm{U} \mathrm{mg}^{-1}$ (FeaB-Kp5.2), 0.020 $\pm 0.001 \mathrm{U} \mathrm{mg}^{-1}$ (StyD-1CP), and $0.011 \pm 0.001 \mathrm{U} \mathrm{mg}^{-1}\left(\mathrm{NADP}^{+}\right)$comparing the enzyme activities towards NAD+. PMS did not serve as co-substrate for FeaB-Kp5.2.

Moreover, the three dehydrogenases were studied towards their capability to convert substituted phenylacetaldehydes in comparison with the non-substituted substrate (Table 3 ). It is very noticeable that FeaB-Kp5.2 showed activities of $10.7 \pm 0.6 \mathrm{U} \mathrm{mg}^{-1}$ (phenylacetaldehyde), $10.7 \pm 1.2 \mathrm{U} \mathrm{mg}^{-1}$ (4chlorophenylacetaldehyde), $9.6 \pm 0.4 \mathrm{U} \mathrm{mg}^{-1}$ (4-fluorophenylacetaldehyde), and $1.0 \pm 0.1 \mathrm{U} \mathrm{mg}^{-1}$ ( $\alpha$-methylphenylacetaldehyde), whereas the enzyme activities of both StyDs are located only in the range of several mU mg-1. StyD-1CP converted phenylacetaldehyde with $0.044 \pm 0.002 \mathrm{U} \mathrm{mg}^{-1}$, and the activity towards 4-fluorophenylacetaldehyde was half as high $\left(0.021 \pm 0.001 \mathrm{U} \mathrm{mg}^{-1}\right)$. The least suitable substrates were the methylated $\left(0.0155 \pm 0.0003 \mathrm{U} \mathrm{mg}^{-1}\right)$ and chloro-substituted ones $(0.009$ $\left.\pm 0.001 \mathrm{U} \mathrm{mg}^{-1}\right)$. In comparison to all other dehydrogenases described here, the most suitable substrate for StyD-CWB2 is 4-fluorophenylacetaldehyde $\left(0.030 \pm 0.001 \mathrm{U} \mathrm{mg}^{-1}\right)$, followed by the non-substituted aldehyde $\left(0.0256 \pm 0.0005 \mathrm{U} \mathrm{mg}^{-1}\right)$ and $\alpha$-methylphenylacetaldehyde $(0.016 \pm$ $0.001 \mathrm{U} \mathrm{mg}^{-1}$ ). This enzyme showed the lowest activity of $0.008 \pm 0.001 \mathrm{U} \mathrm{mg}^{-1}$ towards the chlorosubstituted substrate. To complete the results of our recent study [13], the enzyme activity of FeaB$\mathrm{K}-12$ towards $\alpha$-methylphenylacetaldehyde with $1.6 \pm 0.2 \mathrm{U} \mathrm{mg}^{-1}$ was investigated, too.

For FeaB-Kp5.2 and StyD-CWB2, the activities after 3 months of storage at conditions as mentioned in the "Materials and Methods" section were studied, and a huge difference could be observed. While StyD-CWB2 showed $92.3 \pm 3.9 \%$ of the initial activity after 93 days, the remaining activity in the case of FeaB-Kp.5.2 was only $44.3 \pm 1.6 \%$ after 76 days. For the considerably higher active enzyme FeaB-Kp5.2, a study investigating the temperature stability was additionally performed. Therefore, the enzyme was incubated for $30 \mathrm{~min}$ at $0-50{ }^{\circ} \mathrm{C}$ in steps of $5{ }^{\circ} \mathrm{C}$, and the residual activity after this treatment was compared with the initial activity of the enzyme preparation (Fig. 3).

Besides the activity to oxidize (phenylacet)aldehydes to the corresponding acids, formerly studied dehydrogenases showed an esterase activity, too [10, 32, 34, 40]. This ability can be monitored applying an earlier described photometric assay [10]. The measured molar extinction coefficient for our experimental setting was $3.248 \mathrm{mM}^{-1} \mathrm{~cm}^{-1}$. Regarding the esterase activity, the behavior of the four dehydrogenases studied is very diverse (Table 4). The highest specific activity during the hydrolysis of $p$-nitrophenyl acetate to acetic acid and $p$-nitrophenol could be measured for FeaB-Kp5.2 with $4.1 \pm 0.2 \mathrm{U} \mathrm{mg}^{-1}$, followed by $2.6 \pm 0.5 \mathrm{U} \mathrm{mg}^{-1}$

Table 2 Dehydrogenase activities ${ }^{\mathrm{a}}$ of FeaBs and StyDs depending on co-substrate

\begin{tabular}{lllll}
\hline Dehydrogenase & $\mathrm{NAD}^{+}\left[\mathrm{U} \mathrm{mg}^{-1}\right]$ & $\mathrm{NADP}^{+}[\%]$ & PMS [\%] & Reference \\
\hline FeaB-Kp5.2 & $13.9 \pm 0.7$ & $4.0 \pm 1.2$ & n.a. & This work \\
StyD-1CP & $0.068 \pm 0.001$ & $29.5 \pm 1.6$ & n.m. & This work \\
StyD-CWB2 & $0.0356 \pm 0.0001$ & $31.7 \pm 2.5$ & n.m. & This work \\
FeaB-K-12 & $3.1 \pm 0.2$ & $10.6 \pm 0.3$ & n.a. & This work \\
PadA & 2.66 & 16 fold less & n.m. & {$[10]$} \\
\hline
\end{tabular}

a Data shown are averages of independently measured triplicates

n.a. no measurable activity

n.m. not measured 
Table 3 Enzyme activities ${ }^{\mathrm{a}}$ of FeaBs and StyDs towards non-substituted and three substituted phenylacetaldehydes

\begin{tabular}{|c|c|c|c|c|c|}
\hline \multirow[t]{2}{*}{ Dehydrogenase } & \multicolumn{4}{|c|}{$\begin{array}{l}\text { Dehydrogenase activities }{ }^{\text {a }} \text { towards SOI-1CP produced substrates } * * * \text { [U mg- } \\
\left.{ }_{\text {protein }}\right]\end{array}$} & \multirow[t]{2}{*}{ Reference } \\
\hline & Phenylacetaldehyde & $\begin{array}{l}\text { 4-Chlorophenyl } \\
\text { acetaldehyde }\end{array}$ & $\begin{array}{l}\text { 4-Fluorophenyl } \\
\text { acetaldehyde }\end{array}$ & $\begin{array}{l}\alpha \text {-Methylphenyl } \\
\text { acetaldehyde }\end{array}$ & \\
\hline FeaB-Kp5.2 & $10.7 \pm 0.6$ & $10.7 \pm 1.2$ & $9.6 \pm 0.4$ & $1.0 \pm 0.1$ & This work \\
\hline StyD-1CP & $0.044 \pm 0.002$ & $0.009 \pm 0.001$ & $0.021 \pm 0.001$ & $0.0155 \pm 0.0003$ & This work \\
\hline StyD-CWB2 & $0.0256 \pm 0.0005$ & $0.008 \pm 0.001$ & $0.030 \pm 0.001$ & $0.016 \pm 0.001$ & This work \\
\hline FeaB-K-12 & $6.1 \pm 0.7 *$ & $3.2 \pm 0.6^{* *}$ & $3.1 \pm 0.5^{* *}$ & $1.6 \pm 0.2 * *$ & $\begin{array}{l}* \text { This work/ } \\
* *[13]\end{array}$ \\
\hline FeaB-K-12 & $<0.001$ & n.m. & n.m. & n.m. & {$[12]$} \\
\hline
\end{tabular}

a Data shown are averages of independently measured triplicates

$* * *$ expecting $\alpha$-methyl-phenyl-acetaldehyde

n.m. not measured

(FeaB-K-12) and $1.4 \pm 0.1 \mathrm{U} \mathrm{mg}^{-1}$ (StyD-CWB2). By far, the lowest esterase activity of $0.0264 \pm 0.0001 \mathrm{U} \mathrm{mg}^{-1}$ was detected for StyD-1CP.

\section{Discussion}

\section{Phylogenetic Classification of These PADs}

For visualization of the evolutionary relationship of some already published dehydrogenases and those studied in our former and current research work, a phylogenetic tree (Fig. 4) was calculated with the software MEGA6 using the minimum evolution method and a bootstrap value of 1000 . The phylogenetic tree was constructed by using twelve ALDH, one of the family "Class $3 \mathrm{ALDH}$ " and eleven aromatic ALDHs. The fatty aldehyde dehydrogenase (FADH) of $R$. opacus 1CP was used as outgroup based on the "summary tree of ALDH families" shown previously [1]. This enzyme is a representative of family "Class 3 ALDHs" which have no strict substrate specificity and used both cofactors, $\mathrm{NAD}^{+}$and $\mathrm{NADP}^{+}$. They are involved in different pathways like the metabolism of lipid peroxidation products and longchain fatty aldehydes [1]. In our tree, two main branches are visible. The lower branch is formed by both unspecified ALDHs of R. opacus 1CP and G. rubripertincta CWB2 which had been studied marginal in our former research work [13]. The upper branch is exclusively formed by enzymes belonging to the aromatic ALDHs forming a separate family. Here, they are called FeaB and StyD, respectively. Based on the former study of 145 full-length sequences of aldehyde dehydrogenases, the aromatic aldehyde dehydrogenases have presumable a recent common ancestor because their sequences are closely related to each other [4]. Furthermore, representatives of this family were only found in bacteria and have clear cofactor preferences to $\mathrm{NAD}^{+}$, and they oxidize specific aromatic aldehydes into the corresponding acids $[1,41]$. This branch is subdivided into two twigs, one contains both FeaB enzymes, and the other is built by seven StyD proteins. Thereby, both StyDs originating from R. opacus $1 \mathrm{CP}$ and G. rubripertincta CWB2 seem to be more related to each other in comparison with all other StyDs from the pseudomonads. This assumption is also confirmed by the sequence 


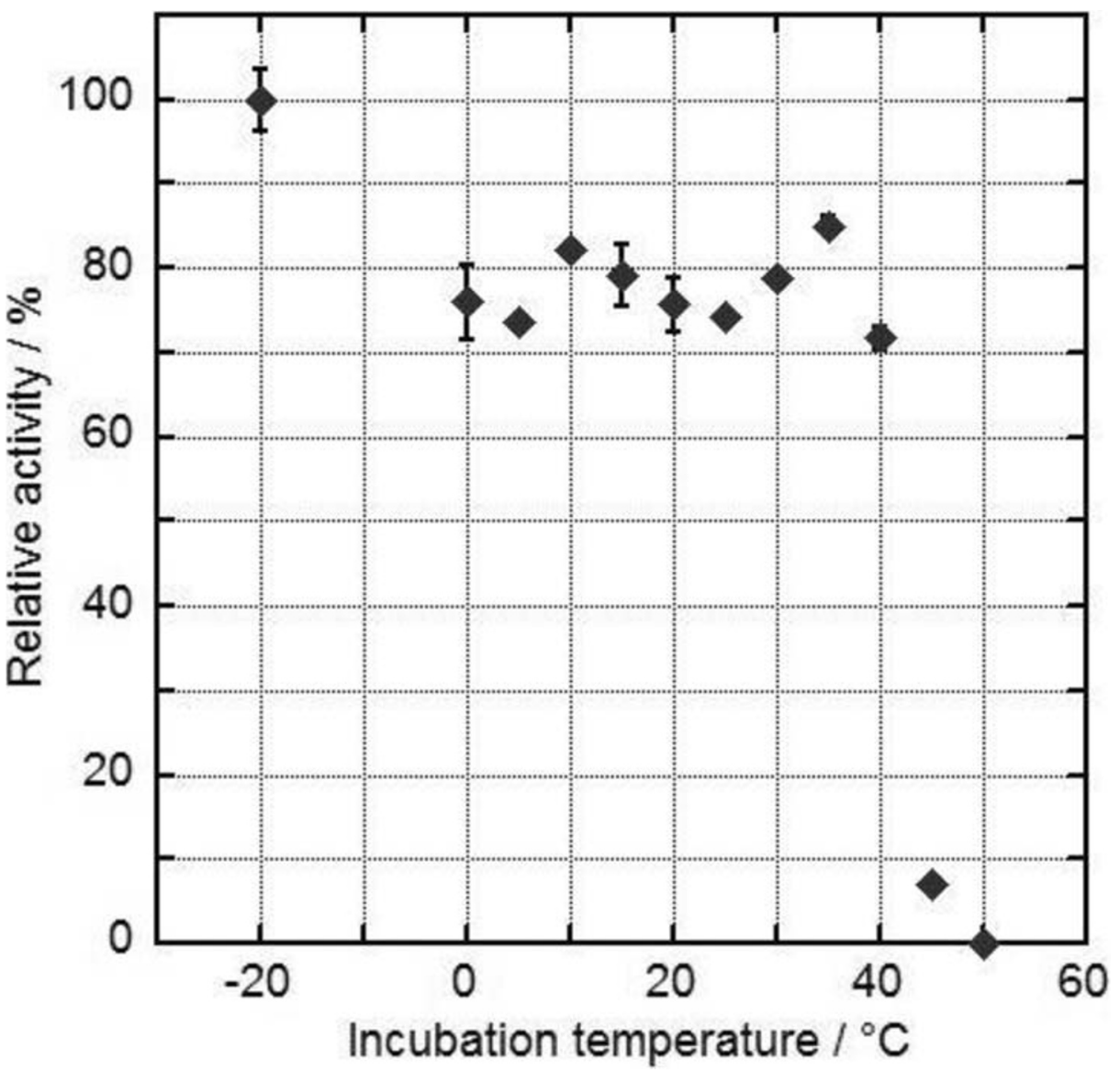

Fig. 3 Relative residual activities of FeaB-Kp5.2 after incubation at temperatures between 0 and $50{ }^{\circ} \mathrm{C}$ in steps of $5{ }^{\circ} \mathrm{C}$. The assay was performed as mentioned in the "Materials and Methods" section. The enzyme was heated up at the desired temperature and incubated for $30 \mathrm{~min}$ before it was investigated by the assay. Relative activities calculated by comparing of the residual activities to the initial activity (value at $-20{ }^{\circ} \mathrm{C} ; 8.40 .3 \mathrm{U} \mathrm{mg}^{-1}$ ) of the enzyme preparation are given. Data shown are averages of independently measured triplicates

identities presented in the "Results" section, chapter "Identification of phenylacetaldehyde dehydrogenases among soil bacteria".

Table 4 Esterase activities ${ }^{\mathrm{a}}$ of FeaBs and StyDs

\begin{tabular}{llll}
\hline Dehydrogenase & Specific esterase activity $\left[\mathrm{U} \mathrm{mg}^{-1}\right]$ & Relative activity* $[\%]$ & Reference \\
\hline FeaB-Kp5.2 & $4.1 \pm 0.2$ & $86 \pm 5.0$ & This work \\
StyD-1CP & $0.0264 \pm 0.0001$ & $60 \pm 0.2$ & This work \\
StyD-CWB2 & $1.38 \pm 0.09$ & $5391 \pm 352$ & This work \\
FeaB-K-12 & $2.6 \pm 0.5$ & $144 \pm 27$ & This work \\
PadA & 0.0056 & 0.3 & {$[10]$} \\
BADH-Pp & 1.94 & 13 & {$[35]$} \\
\hline
\end{tabular}

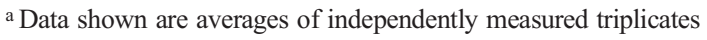

*In comparison with dehydrogenase activity towards the standard substrate phenylacetaldehyde 


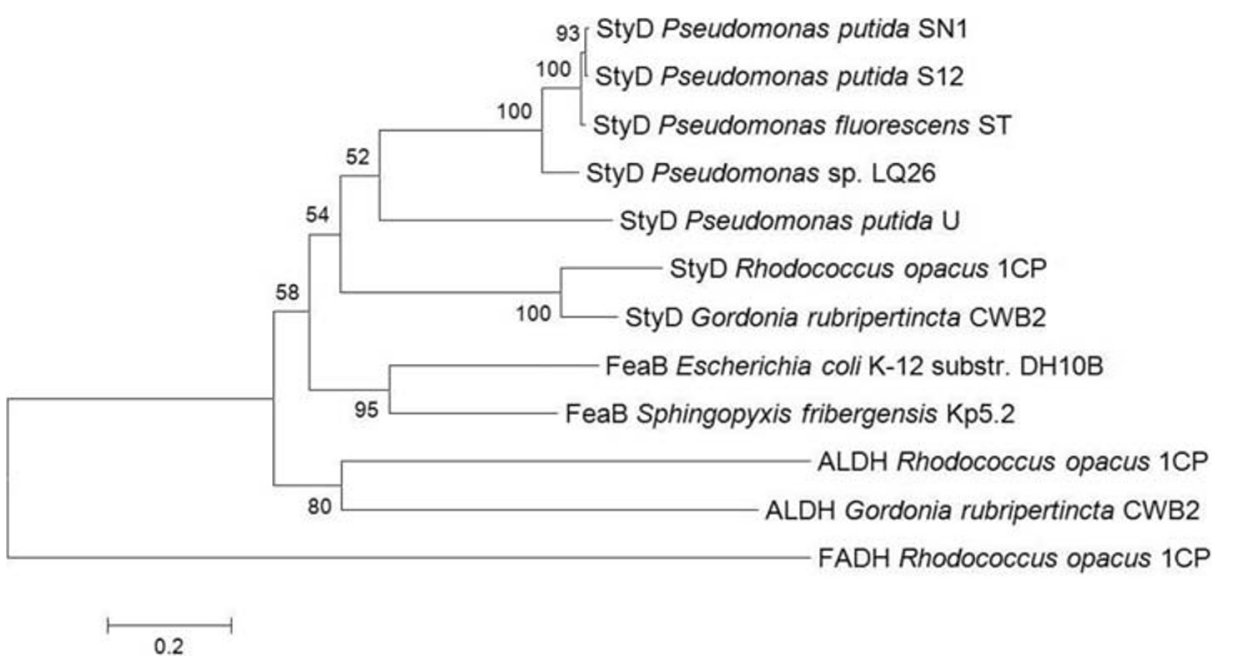

Fig. 4 Phylogenetic analysis of various (phenylacetaldehyde) aldehyde dehydrogenases. The phylogenetic tree was calculated with MEGA6 using the minimum evolution method with 1000 bootstrap replications. Different StyDs originating from various pseudomonads as well as StyDs, FeaBs, and ALDHs from Rhodococcus opacus 1CP, Gordonia rubripertincta CWB2, Escherichia coli K-12 substr. DH10B, and Sphingopyxis fribergensis Kp5.2 are considered

This evolutionary pattern is confirmed by the results of enzyme characterization studies. The enzyme activities of both FeaBs were almost in the same range and obviously distinguished from those of the two StyDs (Table 1, Table 2, Table 3). Both previously characterized ALDHs originating from $R$. opacus $1 \mathrm{CP}$ and G. rubripertincta CWB2 [13] behaved similar to each other and, however, pretty different compared with the FeaBs and StyDs described in the present study. The clustering of the various pseudomonas' StyDs was created by the alignment of the protein sequences. They seem to be quite related to each other. However, statements about the biochemical properties and presumptive similarities cannot be done because of a lack of sufficient data for these enzymes.

\section{Biochemical Characterization}

The three dehydrogenases FeaB-Kp5.2, StyD-1CP, and StyD-CWB2 were recombinantly produced and enriched by Ni-affinity chromatography for detailed biochemical studies. First of all, it must be said that all showed results are activities not of the native but the His $_{10}$-tagged proteins. In former studies, the influences of various His-tags on the $\mathrm{N}$ - and C-termini were investigated [42-49]. On basis of those research works, no uniform statement can be done about the influence of His-tags. Presumably, it depends on the nature of the enzyme, the Histag variant, and location. These investigations tend to result that the His-tags have no or a positive effect on the enzymes' activity [42, 44, 45]. Hence, our findings cannot be deputed on the native dehydrogenases because we studied exclusively the recombinant proteins. Nevertheless, our results about the characterization of the investigated dehydrogenases add valuable knowledge to the field as discussed below.

At the beginning, the Michaelis-Menten kinetic for the co-substrate $\mathrm{NAD}^{+}$was investigated. The results for this study were very different between the FeaBs and StyDs (Table 1). FeaB-Kp5.2 showed a significantly higher enzyme activity. The $\mathrm{V}_{\max }($ app) value was 379 and 456 -times higher 
than those of the StyDs. Compared with a recent study, $\mathrm{V}_{\max }(\mathrm{app})$ of FeaB-Kp5.2 is in the same range than this of FeaB-K-12 [13]. Considering the $\mathrm{K}_{\mathrm{M}}$ (app) value, FeaB-Kp5.2 and both StyDs behave quite different in comparison to FeaB-K-12 [13]. This study revealed the suitable NAD ${ }^{+}$ concentration for these enzymes which were applied for all following investigations.

Following this, the Michaelis-Menten-kinetic for the substrate phenylacetaldehyde (PA) was tested (Fig. 2). For both StyDs, $\mathrm{V}_{\max }(\mathrm{app})$ values of PA kinetics in combination with the suitable $\mathrm{NAD}^{+}$concentration were about 2.5-times higher than those of the co-substrate, but also considerably lower compared with the values measured for the FeaB enzymes. Considering all $\mathrm{V}_{\max }(\mathrm{app})$ values, both FeaBs are the much more active compared with the investigated StyDs. As expected, this is supported by the corresponding $\mathrm{k}_{\text {cat }}(\mathrm{app})$ values (Table 1). Under these experimental conditions, there are tremendous differences between the FeaBs and StyDs. The lowest turnover numbers of about 7 and 9 were reached for StyD-1CP and StyDCWB2, respectively. In contrast, both FeaBs reached significantly higher $\mathrm{k}_{\text {cat }}$ (app) values of 709 (FeaB-K-12) and 1718 (FeaB-Kp5.2). In summary, the FeaB-related enzymes exceed the turnover number of the StyDs by roughly 100-240 times.

Aldehyde dehydrogenases are necessarily addicted to co-substrate due to their mechanism [2]. Here, we tested $\mathrm{NAD}^{+}, \mathrm{NADP}^{+}$, and PMS as electron acceptor (Table 2). Interestingly in this characteristic, all four investigated enzymes showed the same preference. The enzyme activity by applying $\mathrm{NAD}^{+}$was the highest, by far. Using these activity values as reference, the residual activities during phenylacetaldehyde transformations with the co-substrate NADP ${ }^{+}$ under standard conditions were only $31.7 \pm 2.5$ (StyD-CWB2), $29.5 \pm 1.6$ (StyD-1CP), $10.6 \pm$ 0.3 (FeaB-K-12), [13] and $4.0 \pm 1.2 \%$ (FeaB-Kp5.2). In analogy to the previously characterized FeaB-K-12 [13], we tested the capability of PMS as co-substrate for FeaB-Kp5.2. Indeed, there was no measureable enzyme activity by applying PMS, too. Respectively, it can be concluded that phenylacetaldehyde dehydrogenases even if they originate from different pathways are $\mathrm{NAD}^{+}$-dependent and rather specific for this co-substrate. In case of the degradation of styrene, this makes sense as here the first enzyme of this pathway, the styrene monooxygenase (StyAB), utilizes $\mathrm{NADH}$ and thus provides $\mathrm{NAD}^{+}$which could be used by StyDs or FeaBs. This is reported as a natural intrinsic enzyme cascade [8].

Moreover, all three dehydrogenases were studied towards their capability to convert substituted phenylacetaldehydes in comparison with the non-substituted one (Table 3). FeaB-Kp5.2 was able to metabolized 4-chlorophenylacetaldehyde as good as phenylacetaldehyde. Residual activities of $90 \pm 4$ and $9 \pm 1 \%$ were detected towards 4fluoro- and $\alpha$-methylphenylacetaldehyde. As expected, both FeaBs behave similar in this context. They showed the highest relative enzyme activities in the presence of the nonsubstituted phenylacetaldehyde and the lowest during $\alpha$-methylphenylacetaldehyde conversion. Regarding to the halogenated substrates, the enzyme activities of FeaB-K-12 were obviously lower [13]. During the $\alpha$-methylphenylacetaldehyde oxidation, both FeaBs showed nearly the same absolute enzyme activity. So, this is the only substrate which is metabolized slightly faster by FeaB-K-12 instead of FeaB-Kp5.2. For the other three substrates, FeaBKp5.2 showed about two times higher transformation rates in comparison with FeaB-K-12. However, both StyD proteins showed completely different characteristics. In the case of StyD$1 \mathrm{CP}$, the non-substituted phenylacetaldehyde was the best substrate, whereas this enzyme converted 4-fluoro- and 4-chlorophenylacetaldehyde with relative activities about half and one-fifth. StyD-CWB2 acted as an exception because the highest activity of $116 \pm 5 \%$ in comparison with phenylacetaldehyde was measured in the presence of 4fluorophenylacetaldehyde. Towards $\alpha$-methylphenylacetaldehyde, StyD-CWB2 showed the 
highest relative enzyme activity measured for this substrate, so far. The enzyme from CWB2 showed its lowest activity for 4-chlorophenylacetaldehyde. The reduced capability to transform the chloro-substituted substrate was also determined for StyD-1CP. This aspect indicates a remarkable difference of both StyDs towards the FeaBs. In summary and based on the total activities determined in our study, FeaB-Kp5.2 is the most active enzyme towards phenylacetaldehyde and the halogenated substrates with very high activities of $90-100 \%$, while FeaB-K-12 is the most active enzyme towards $\alpha$-methylphenylacetaldehyde.

Besides the substrate spectra of these enzymes, the stability regarding to two different aspects was additionally studied: the long-term storage over about 3 months at $-20^{\circ} \mathrm{C}$ and the stability towards temperatures in the range of $0-55^{\circ} \mathrm{C}$ (Fig. 3). FeaB-Kp5.2 showed a high stability with a residual activity of $44.3 \pm 1.6 \%$ compared with the initial activity after 76 days at $-20{ }^{\circ} \mathrm{C}$. Surprisingly, the long-term stability of StyD-CWB2 was even higher. That enzyme lost only about $8 \%$ of its initial activity after 93 days. Furthermore, the stability of FeaB-Kp5.2 towards temperatures up to $40{ }^{\circ} \mathrm{C}$ (Fig. 3) was notable because residual activities of $85-72 \%$ were measured after 30 -min incubation at $0-40{ }^{\circ} \mathrm{C}$ compared with the initial activity at $-20{ }^{\circ} \mathrm{C}$. For temperatures between $40{ }^{\circ} \mathrm{C}(71.7 \pm 1.4 \%)$ and $45^{\circ} \mathrm{C}$, the residual enzyme activity decreased tremendously to $6.9 \pm 0.1 \%$. No residual activity could be determined after incubating the enzyme at a temperature of $50{ }^{\circ} \mathrm{C}$ indicating a total inactivation of the dehydrogenase. These results for FeaB-Kp5.2 were again similar to those of FeaB-K-12 [13]. Due to the already low enzyme activities for both StyDs, no temperature stability experiments were performed.

ALDHs are known to show dehydrogenase as well as esterase activity. Against former assumptions [50], numerous evidences were found that these enzymes catalyze both distinct reactions in one single active site [51]. These both catalytic functions were first revealed for horse and human liver aldehyde dehydrogenases [40, 52]. Also the bacterial ALDH, PadA from Escherichia coli W, was found to have esterase activity $[10,32]$. The comparison of the $E$. coli dehydrogenase and esterase activities is hardly possible because the experimental conditions of our and the former study of Ferrández and colleagues (1997) were not similar. However, PadA of E. coli $\mathrm{W}$ had shown an extremely slight esterase activity of less than $0.3 \%$ $\left(5.6 \mathrm{mU} \mathrm{mg}^{-1}\right.$ ) compared with its dehydrogenase activity. In our study, all four tested enzymes showed an esterase activity, too (Table 4). In comparison with the PAD dehydrogenase activity, huge distinctions were determined. Whereas FeaB-K-12 showed a relative esterase activity of $144 \pm 27 \%$ compared with its dehydrogenase activity, the esterase activities of FeaB-Kp5.2 $(86 \pm 5 \%)$ and StyD-1CP $(60.0 \pm 0.2 \%)$ were lower compared with their dehydrogenase activity (Table 3). Nevertheless, StyD-CWB2 showed a tremendous higher esterase than dehydrogenase activity of $5391 \pm 352 \%$. This result could give an assumption of the origin of the StyD originating from G. rubripertincta CWB2. Furthermore, this strain has a totally different pathway for styrene [36]. Both aspects strongly indicate that the pathway and the enzymes included were assembled from various other metabolic ways and sources.

\section{Future Prospectives of These Dehydrogenases}

In our study, we have presented entirely novel data about PADs of three styrene-degrading soil bacteria. The results shown differences between these enzymes especially regarding their activities and substrate specificities. So far, FeaB-Kp5.2 could be highlighted as the most active PAD. Hence, we have created a basis of further studies with respect to biotechnological phenylacetic acid syntheses. Therefore, a combination of PAD with SOI and SMO could be practicable for the eco-friendly product of the high-grade phenylacetic acids from simple 
available styrenes. In contrast to the chemical syntheses, the biotechnological production could be performed under physiological conditions, without plenty of acids and bases and without toxic by-products, too. Hence from an ecological point of view, the development of biotechnological phenylacetic acid synthesis routes is a serious alternative to the current processes.

Acknowledgement Juliane Zimmerling, Michel Oelschlägel, and Dirk Tischler were supported by the Deutsche Bundesstiftung Umwelt (DBU) with pre-doctoral scholarships (JZ: 20013/289; MO: 20011/126; DT: 20007/939). Furthermore, Michel Oelschlägel was supported by project grants of the DBU (32149/01) as well as of the Dr. Erich-Krüger-foundation and Dirk Tischler by a grant of the European Social Fund (ESF) and the Saxonian Government (GETGEOWEB: 100101363) as well as the Federal Ministry of Education and Research (BakSolEx: 033R147).

Funding Open Access funding enabled and organized by Projekt DEAL.

\section{Compliance with Ethical Standards}

Conflict of Interest All authors declare that they have no conflict of interest.

Open Access This article is licensed under a Creative Commons Attribution 4.0 International License, which permits use, sharing, adaptation, distribution and reproduction in any medium or format, as long as you give appropriate credit to the original author(s) and the source, provide a link to the Creative Commons licence, and indicate if changes were made. The images or other third party material in this article are included in the article's Creative Commons licence, unless indicated otherwise in a credit line to the material. If material is not included in the article's Creative Commons licence and your intended use is not permitted by statutory regulation or exceeds the permitted use, you will need to obtain permission directly from the copyright holder. To view a copy of this licence, visit http://creativecommons.org/licenses/by/4.0/.

\section{References}

1. Perozich, J., Nicholas, H., Lindahl, R., \& Hempel, J. (1999). In H. Weiner et al. (Eds.), Enzymology and molecular biology of carbonyl metabolism 7, vol. 463: The big book of aldehyde dehydrogenase sequences. An overview of the extended family (pp. 1-7). New York: Springer Science+Business Media.

2. Crabo, A. G., Singh, B., Nguyen, T., Emami, S., Gassner, G. T., \& Sazinsky, M. H. (2017). Structure and biochemistry of phenylacetaldehyde dehydrogenase from Pseudomonas putida S12 styrene catabolic pathway. Archives of Biochemistry and Biophysics, 616, 47-58.

3. Hempel, J., Perozich, J., Chapman, T., Rose, J., Boesch, J. S., Liu, Z.-J., Lindahl, R., \& Wang, B.-C. (1999). In H. Weiner et al. (Eds.), Enzymology and Molecular Biology of Carbonyl Metabolism 7, vol. 463: Aldehyde dehydrogenase catalytic mechanism. A proposal (pp. 53-59). New York: Springer Science+ Business Media.

4. Perozich, J., Nicholas, H., Wang, B., Lindahl, R., \& Hempel, J. (1999). Relationship within the aldehyde dehydrogenase extended family. Protein Science, 1/8, 137-146.

5. O'Leary, N. D., O'Connor, K. E., \& Dobson, A. D. W. (2002). Biochemistry, genetics and physiology of microbial styrene degradation. FEMS Microbiology Reviews, 26(4), 403-417.

6. Hartmans, S., Van der Werf, M. J., \& de Bont, J. A. M. (1990). Bacterial degradation of styrene involving a novel flavin adenine dinucleotide-dependent styrene monooxygenase. Applied and Environmental Microbiology, 56(5), 1347-1351.

7. Teufel, R., Mascaraque, V., Ismail, W., Voss, M., Perera, J., Eisenreich, W., Haehnel, W., \& Fuchs, G. (2010). Bacterial phenylalanine and phenylacetate catabolic pathway revealed. Proceedings of the National Academy of Sciences, 107(32), 14390-14395.

8. Oelschlägel, M., Zimmerling, J., \& Tischler, D. (2018). A review: the styrene metabolizing cascade of sidechain oxygenation as biotechnological basis to gain various valuable compounds. Frontiers in Microbiology, 9, 1-17. 
9. Beltrametti, F., Marconi, A. M., Bestetti, G., Colombo, C., Galli, E., Ruzzi, M., \& Zennaro, E. (1997). Sequencing and functional analysis of styrene catabolism genes from Pseudomonas fluorescens ST. Applied and Environmental Microbiology, 63(6), 2232-2239.

10. Ferrández, A., Prieto, M. A., García, J. L., \& Díaz, E. (1997). Molecular characterization of PadA, a phenylacetaldehyde dehydrogenase from Escherichia coli. FEBS Letters, 406(1-2), 23-27.

11. Hanlon, S. P., Hill, T. K., Flavell, M. A., Stringfellow, J. M., \& Cooper, R. A. (1997). 2-Phenylethylamine catabolism by Escherichia coli K-12 : gene organization and expression. Microbiology, 143(2), 513-518.

12. Parrott, S., Jones, S., \& Cooper, R. A. (1987). 2-Phenylethylamine catabolism by Escherichia coli K12. Journal of General Microbiology, 133(2), 347-351.

13. Zimmerling, J., Tischler, D., Großmann, C., Schlömann, M., \& Oelschlägel, M. (2017). Characterization of aldehyde dehydrogenases applying an enzyme assay with in situ formation of phenylacetaldehydes. Biotechnology and Applied Biochemistry, 182(3), 1095-1107.

14. Shimizu, E., Ichise, H., Odawara, T., \& Yorifuji, T. (1993). NADP-dependent phenylacetaldehyde dehydrogenase for degradation of phenylethylamine in Arthrobacter globiformis. Bioscience, Biotechnology, and Biochemistry, 57(5), 852-853.

15. Hartmans, S., Smits, J. P., van der Werf, M. J., Volkering, F., \& de Bont, J. A. M. (1989). Metabolism of styrene oxide and 2-phenylethanol in the styrene-degrading Xanthobacter strain 124X. Applied and Environmental Microbiology, 55(11), 2850-2855.

16. Cox, H. H. J., Faber, B. W., Van Heiningen, W. N. M., Radhoe, H., Doddema, H. J., \& Harder, W. (1996). Styrene metabolism in Exophiala jeanselmei and involvement of a cytochrome P-450-dependent styrene monooxygenase. Applied and Environmental Microbiology, 62(4), 1471-1474.

17. Taqui Khan, M. M., Halligudi, S. B., \& Abdi, S. H. R. (1988). Carbonylation of benzyl chloride to phenylacetic acid and its ester using water-soluble Ru(III)-EDTA complex catalyst. Journal of Molecular Catalysis, 44(2), 179-181.

18. Fahlbusch, K.-G., Hammerschmidt, F.-J., Panten, J., Pickenhagen, W., Schatkowski, D., Bauer, K., Garbe, D., \& Surburg, H. (2012). Flavors and Fragrances (Vol. 15). Weinheim: Wiley-VCH Verlag GmbH \& Co. KGaA.

19. Milne, J. E., Storz, T., Colyer, J. T., Thiel, O. R., Seran, M. D., Larsen, R. D., \& Murry, J. A. (2011). Iodide-catalyzed reductions: development of a synthesis of phenylacetic acids. The Journal of Organic Chemistry, 76(22), 9519-9524.

20. Wei, L., Shi, Q., Bastow, K. F., Brossi, A., Morris-Natschke, S. L., Nakagawa-Goto, K., Wu, T.-S., Pan, S.L., Teng, C.-M., \& Lee, K.-H. (2007). Antitumor agents 253. Design, synthesis, and antitumor evaluation of novel 9-substituted phenanthrene-based tylophorine derivatives as potential anticancer agents. Journal of Medicinal Chemistry, 50(15), 3674-3680.

21. Luo, Y., Li, Y., Qiu, K.-M., Lu, X., Fu, J., \& Zhu, H.-L. (2011). Metronidazole acid acyl sulfonamide: A novel class of anticancer agents and potential EGFR tyrosine kinase inhibitors. Bioorganic \& Medicinal Chemistry, 19(20), 6069-6076.

22. Jiang, J., DeVita, R.J., Kumar, S., Mills, S.G., \& Tschirret-Guth, R.A. (2010). United States Patent, US7683068, Merck Sharp \& Dohme Corp., US.

23. Chen, A., Ren, L., \& Crudden, C. M. (1999). Catalytic asymmetric hydrocarboxylation and hydrohydroxymethylation. A two-step approach to the enantioselective functionalization of vinylarenes. The Journal of Organic Chemistry, 64(26), 9704-9710.

24. Small, R. E. (1989). Diclofenac sodium. Clinical Pharmacology, 8(8), 545-558.

25. Keiji Kagawa, O., Kanda, N., Masuko, F., \& Nakanishi, H. (1980). United States Patent, US4220592, Sumitomo Chemical Company, Japan.

26. Qiu, Z., He, Y., Zheng, D., \& Liu, F. (2005). Study on the synthesis of phenylacetic acid by carbonylation of benzyl chloride under normal pressure. Journal of Natural Gas Chemistry, 14(1), 40-46.

27. Tischler, D., Eulberg, D., Lakner, S., Kaschabek, S. R., Van Berkel, W. J. H., \& Schlömann, M. (2009). Identification of a novel self-sufficient styrene monooxygenase from Rhodococcus opacus 1CP. Journal of Bacteriology, 191(15), 4996-5009.

28. Oelschlägel, M., Rückert, C., Kalinowski, J., Schmidt, G., Schlömann, M., \& Tischler, D. (2015). Sphingopxyis fribergensis sp. nov., a soil bacterium with the ability to degrade styrene and phenylacetic acid. International Journal of Systematic and Evolutionary Microbiology, 65(9), 3008-3015.

29. Gorlatov, S. N., Mal'tseva, O. V., Shevchenko, V. I., \& Golovleva, L. A. (1989). Degradation of chlorophenols by a culture of Rhodococcus erythropolis. Microbiology, 58(5), 647-651.

30. Oelschlägel, M., Kaschabek, S. R., Zimmerling, J., Schlömann, M., \& Tischler, D. (2015). Co-metabolic formation of substituted phenylacetic acids by styrene-degrading bacteria. Biotechnology Reports., 6, 20-26.

31. Puigbò, P., Guzmán, E., Romeu, A., \& Garcia-Vallvé, S. (2007). OPTIMIZER: a web server for optimizing the codon uasge of DNA sequences. Nucleic Acids Research, 35(Web Server issue), W126-W131.

32. Rodríguez-Zavala, J. S., Allali-Hassni, A., \& Weiner, H. (2006). Characterization of E. coli tetrameric aldehyde dehydrogenases with atypical properties compared to other aldehyde dehydrogenases. Protein Science, 15(6), 1387-1396. 
33. Bradford, M. M. (1976). A rapid and sensitive method for the quantitation of microgram quantities of protein utilizing the principle of protein-dye binding. Analytical Biochemistry, 72(1-2), 248-258.

34. Weiner, H., Hu, J. H., \& Sanny, C. G. (1976). Rate-limiting steps for the esterase and dehydrogenase reaction catalyzed by horse liver aldehyde dehydrogenase. The Journal of Biological Chemistry, 251(13), 3853-3855.

35. Shaw, J. P., \& Harayama, S. (1990). Purification and characterisation of TOL plasmid-encoded benzyl alcohol dehydrogenase and benzaldehyde dehydrogenase of Pseudomonas putida. European Journal of Biochemistry, 191(3), 705-714.

36. Heine, T., Zimmerling, J., Ballmann, A., Kleeberg, S. B., Rückert, C., Busche, T., Winkler, A., Kalinowski, J., Poetsch, A., Scholtissek, A., Oelschlägel, M., Schmidt, G., \& Tischler, D. (2018). On the enigma of glutathione-dependent styrene degradation in Gordonia rubripertincta CWB2. Applied and Environmental Microbiology, 84(9), 1-16.

37. Tischler, D., Kermer, R., Gröning, J. A. D., Kaschabek, S. R., van Berkel, W. J. H., \& Schlömann, M. (2010). StyA1 and StyA2B from Rhodococcus opacus 1CP: a multifunctional styrene monooxygenase system. Journal of Bacteriology, 192(19), 5220-5227.

38. Oelschlägel, M., Zimmerling, J., Schlömann, M., \& Tischler, D. (2014). Styrene oxide isomerase of Sphingopyxis sp. Kp5.2. Microbiology, 160(11), 2481-2491.

39. Riedel, A., Heine, T., Westphal, A. H., Conrad, C., Rathsack, P., Van Berkel, W. J. H., \& Tischler, D. (2015). Catalytic and hydrodynamic properties of styrene monooxygenases from Rhodococcus opacus 1CP are modulated by cofactor binding. AMB Express, 5(1), 112.

40. Sidhu, R. S., \& Blair, A. H. (1975). Human liver aldehyde dehydrogenase. The Journal of Biological Chemistry, 250(19), 7894-7898.

41. Liu, Z.-J., Sun, Y.-J., Rose, J., Chung, Y.-J., Hsiao, C.-D., Chang, W.-R., Kuo, I., Perozich, J., Lindahl, R., Hempel, J., \& Wang, B.-C. (1997). The first structure of an aldehyde dehydrogenase reveals novel interactions between NAD and the Rossmann fold. Nature Structural \& Molecular Biology, 4(4), 317-326.

42. Carson, M., Johnson, D. H., McDonald, H., Brouillette, C., \& DeLucas, L. J. (2006). His-tag impact on structure. Acta Crystallographica Section C, 63(Pt 3), 295-301.

43. Klose, J., Wendt, N., Kubald, S., Krause, E., Fechner, K., Beyermann, M., Bienert, M., Rdolph, R., \& Rothemund, S. (2004). Hexa-histidin tag postion influecnes disulfide structure but not binding behaviour of in vitro folded N-terminal domain of rat corticotropin-releasing factor receptor type 2a. Protein Science, 13(9), 2470-2475.

44. Ferenc-Mrozek, A., Bojarska, E., Stepinski, J., Darzynkiewicz, E., \& Lukaszewicz, M. (2020). Effect of the His-tag location on decapping scavenger enzymes and their hydrolytic activity toward cap analogs. ACS Omega, 5(19), 10759-10766.

45. Rumsfeld, J., Ziegelbauer, K., \& Spaltmann, F. (2000). High-throughput assay for inorganic pyrophosphatases using the cytosolic enzymes of Saccharomyces cerevisiae and human as an example. Protein Expression and Purification, 18(3), 303-309.

46. Liu, W., Zhang, X.-Z., Zhang, Z., \& Zhang, Y.-H. (2010). Engineering of Clostridium phytofermentans endoglucanase Cel5A for improved thermostability. Applied and Environmental Microbiology, 76(14), 49144917.

47. Ledent, P., Duez, C., Vanhoe, M., Lejeune, A., Fonzé, E., Charlier, P., Rhazi-Filali, F., Thamm, I., Guillaume, G., Samyn, B., Devreese, B., Van Beeeumen, J., Lamotte-Brasseur, J., \& Frère, J.-M. (1997). Unexpected influence of a C-terminal-fused His-tag on the processing of an enzyme and on the kinetic and folding paramters. FEBS Letters, 413(2), 194-196.

48. Bulut, D., Duangdee, N., Gröger, H., Berkessel, A., \& Hummel, W. (2016). Screening, molecular cloning, and biochemical characterization of an alcohol dehydrogenase from Pichia pastoris useful for the kinetic resolution of a racemic $\beta$-hydroxy- $\beta$-trifluoromethyl ketone. ChemBioChem, 17(14), 1349-1358.

49. Sabaty, M., Grosse, S., Adryanczyk, G., Boiry, S., Biaso, F., Arnoux, P., \& Pignol, D. (2013). Detrimental effect of the 6 His C-terminal tag on YedY enzymatic activity and influence of the TAT signal sequence on YedY synthesis. BMC Biochemistry, 14(1), 28.

50. Blackwell, L. F., Bennett, A. F., \& Buckley, P. D. (1983). Relationship between the mechanisms of the esterase and dehydrogenase activities of the cytoplasmic aldehyde dehydrogenase from sheep liver. An alternative view. Biochemistry, 22(16), 3784-3791.

51. Duncan, R. J. S. (1985). Aldehyde dehydrogenase. An enzyme with two distinct catalytic activities at a single type of active site. Biochemical Journal, 230(1), 261-267.

52. Feldman, R. I., \& Weiner, H. (1972). Horse liver aldehyde dehydrogenase. The Journal of Biological Chemistry, 247(1), 267-272.

Publisher's Note Springer Nature remains neutral with regard to jurisdictional claims in published maps and institutional affiliations. 